DOI:10.17951/h.2020.54.4.69-81

\begin{tabular}{lcc}
\hline \multicolumn{3}{c}{ A N N A L E S } \\
UNIVERSITATIS MARIAE CURIE-SKŁODOWSKA \\
LUBLIN - POLONIA \\
VOL. LIV, 4 & SECTIOH H \\
\hline
\end{tabular}

\author{
PATRYCJA MARZEC \\ patrycja.marzec@umcs.pl \\ Uniwersytet Marii Curie-Skłodowskiej w Lublinie. Wydział Ekonomiczny \\ pl. Marii Curie-Skłodowskiej 5, 20-031 Lublin, Polska \\ ORCID ID: https://orcid.org/0000-0001-7593-6901
}

\title{
Wyzwania współczesnych przedsiębiorców a sukces Doliny Krzemowej
}

Challenges of Modern Entrepreneurs and Success of Silicon Valley

Keywords: entrepreneur; leader; competences of the future

Słowa kluczowe: przedsiębiorca; przywódca; kompetencje przyszłości

JEL: O15; O32; O34; O36

Propozycja cytowania: Marzec, P. (2020). Wyzwania współczesnych przedsiębiorców a sukces Doliny Krzemowej. Annales Universitatis Mariae Curie-Skłodowska, sectio H-Oeconomia, Vol. 54, No. 4.

\footnotetext{
Abstract

Theoretical background: Dynamic technological, social and civilization changes, as well as progressing globalization, significantly increase the level of difficulties faced by modern entrepreneurs. The turbulent and complex nature of the environment adversely affects the accurate prediction of the future, which makes it difficult to correctly adjust the specificity of the business to the needs of potential customers.

Purpose of the article: Identification of the desired features of the leader of the $21^{\text {st }}$ century and diagnosis of changes in the environment and the challenges facing the organization of the future, as well as analysis of the key success factors of Silicon Valley.

Research methods: The article is based on a literature review on the subject. A critical analysis of the attributes that distinguish a contemporary leader, changes taking place in the organization and its environment, as well as the region that inspires entrepreneurs.
} 
Main findings: The need for entrepreneurs to dynamically adapt to the changing needs of customers, to rely on the idea of a learning organization and promote social responsibility, to treat employees as the most valuable resource, to strive for cooperation and building a network of relationships in a multicultural environment, as well as to introduce modern solutions corresponding to changes caused by fourth industrial revolution.

\begin{abstract}
Abstrakt
Uzasadnienie teoretyczne: Dynamiczne przemiany technologiczne, społeczne i cywilizacyjne, a także postępująca globalizacja znacząco potęgują stopień trudności stawiany współczesnym przedsiębiorcom. Burzliwy i złożony charakter otoczenia wpływa niekorzystnie na trafne przewidywanie przyszłości, przez co występują trudności w prawidłowym dostosowywaniu specyfiki prowadzonej działalności do potrzeb potencjalnych klientów.

Cel artykułu: Identyfikacja pożądanych cech przywódcy XXI wieku oraz diagnoza zmian zachodzących w otoczeniu i wyzwań, jakie stoją przed organizacją przyszłości, a także analiza kluczowych czynników sukcesu Doliny Krzemowej.

Metody badawcze: Artykuł powstał w oparciu o przegląd literatury przedmiotu. Dokonano krytycznej analizy atrybutów wyróżniających współczesnego przywódcę, zmian zachodzących w organizacji i jej otoczeniu, a także regionu będącego inspiracją dla przedsiębiorców.

Główne wnioski: Dostrzeżono konieczność dynamicznego dostosowania się przedsiębiorców do zmieniających się potrzeb klientów, bazowania na idei organizacji uczącej się i propagowania społecznej odpowiedzialności, traktowania pracowników jako najcenniejszego zasobu, dążenia do współpracy i budowania sieci relacji w wielokulturowym otoczeniu oraz wprowadzania nowoczesnych rozwiązań, odpowiadających zmianom wywołanym przez czwartą rewolucję przemysłową.
\end{abstract}

\title{
Wprowadzenie
}

Przemiany cywilizacyjne, szybko postępująca globalizacja oraz nieoczekiwane zmiany technologiczne i społeczne przyczyniają się do tworzenia niekonwencjonalnych sposobów zarządzania współczesnymi organizacjami. Przedsiębiorcy mają trudności z dostosowaniem specyfiki organizacji do potrzeb niezwykle wymagających klientów. Na rynku pojawiają się nowsze i bardziej nieprzewidywalne wyzwania stawiane przez firmy konkurencyjne, które w dynamicznym tempie tworzą innowacyjne rozwiązania, wykorzystując pojawiające się szanse rynkowe. W efekcie wiele przedsięwzięć kończy się porażką, a ludzie przedsiębiorczy niechętnie podejmują ryzyko związane z założeniem własnego biznesu.

Celem artykułu jest identyfikacja pożądanych cech przywódcy XXI wieku, a także diagnoza zmian zachodzących we współczesnej organizacji i jej otoczeniu, co przyczyni się do wyodrębnienia społecznych, technologicznych i globalnych wyzwań stojących przed organizacją przyszłości. Z kolei analiza kluczowych czynników sukcesu Doliny Krzemowej umożliwi wskazanie wyznaczników sukcesu dla początkujących przedsiębiorców. Opracowanie powstało w oparciu o przegląd literatury przedmiotu. 


\section{Przedsiębiorca XXI wieku jako przywódca ukierunkowany na zmiany}

Współcześnie świat biznesu kreuje coraz bardziej złożone i niepowtarzalne cele organizacji. Menedżerowie są postawieni przed koniecznością wychodzenia naprzeciw nie tylko potrzebom klientów, ale również samych podwładnych. Ewolucja organizacji pracy zmierza w kierunku autonomizacji oraz tworzenia bardzo elastycznych form pracy. Nacisk kładziony jest na systematyczne podnoszenie umiejętności poszczególnych pracowników, dla których awans pionowy nie jest już przejawem sukcesu zawodowego (Dźwigoł, 2014). Rozwój i funkcjonowanie przedsiębiorstw uzależnione są od utalentowanych, aktywnych i świadomych swej roli pracowników, sukcesywnie podnoszących swoje kompetencje i kwalifikacje, posiadających aspiracje, dążących do zdobywania wiedzy i opierających swój sukces na nowych wzorach kariery bez granic (Klimka-Kołysko, 2018). Poprzez dynamiczny postęp cywilizacyjny permanentnie wzrasta znaczenie procedur myślowych, które są ukierunkowane na trafne i uogólnione identyfikowanie zjawisk występujących w otoczeniu. W następstwie tego konieczna staje się szczegółowa weryfikacja relacji na płaszczyźnie percepcja menedżera - właściwości otoczenia. Niezwykle istotne okazują się tutaj umiejętności i zdolności strukturalizowania informacji, które umożliwiają twórczą syntezę i analizę danych, a także krytyczne podejście do własnych poglądów. W efekcie współczesny menedżer osiąga pełną satysfakcję z życia zawodowego w momencie, gdy kariera zawodowa staje się dla niego drogą do profesjonalnej doskonałości (Kiełtyka, 2016).

W literaturze przedmiotu funkcjonuje wiele definicji przywództwa, najczęściej jednak wskazuje się, że jest ono zarówno procesem, jak i pewną właściwością (Jago, 1982). Przywództwo jako proces to pozbawiony przymusu wpływ na kształtowanie celów danej grupy lub organizacji, motywowanie zachowań, które umożliwiają osiągnięcie tych celów oraz przyczynianie się do definiowania kultury danej grupy lub organizacji. Z kolei jako właściwość jest ono zestawem cech, które można przypisać osobom postrzeganym jako przywódcy. Przywództwo wskazuje kierunek zmian oraz tworzy strategie działania, na które wpływa poprzez liczne techniki motywacyjne. Umożliwia też dostrzeganie niezaspokojonych potrzeb oraz trudności i barier powstałych na skutek relacji międzyludzkich (Kotter, 2001). Współczesne przywództwo powinno być ukonstytuowane na humanistycznych wartościach, odpowiedzialne moralnie i akceptowane społecznie. Z kolei liderzy (przywódcy) powinni nie tylko rozumieć i przestrzegać tych wartości, ale w szczególności nadawać im znaczenie, nakreślać kierunki rozwoju oraz wspierać organizacyjne uczenie się. Znaczenie przywódcy w gospodarce opartej na wiedzy znacząco wzrasta - lider ma wpływ na strategię przedsiębiorstwa, procesy zarządzania i kształt kultury organizacyjnej oraz potrafi umiejętnie wykorzystywać zasoby intelektualne pracowników i potencjał techniczny (Zgoda, Nowakowska, \& Nowakowska, 2017). Niewątpliwie podstawową cechą przywódcy jest przewodzenie ludźmi, które obejmuje całą złożoność roli, jaką pełni lider, a więc osoba sprawująca władzę nad innymi (Geryk, 2016). Przywódcę 
- w odróżnieniu od pozostałych członków organizacji - wyróżnia zapał, uczciwość i prawość, dążenie do przewodzenia, pewność siebie, wiedza o przedmiocie zarządzania oraz zdolności poznawcze (Bass \& Bass, 2008).

Główną rolą współczesnego menedżera jest umiejętne połączenie trzech walorów: wiedzy, sztuki zarządzania i charyzmy, przy jednoczesnym silnym ukierunkowaniu na umiejętne zarządzanie zachodzącymi wewnątrz i na zewnątrz relacjami międzyludzkimi (Geryk, 2016). Na podstawie literatury przedmiotu w tabeli 1 zamieszczono katalog pożądanych predyspozycji menedżera XXI wieku, przy czym przyporządkowano je do trzech głównych kategorii, wyodrębniając atrybuty osobowościowe, intelektualne oraz uwzględniające relacje przywódcy z organizacją i jej otoczeniem.

Tabela 1. Atrybuty współczesnego przywódcy

\begin{tabular}{|c|c|}
\hline \multicolumn{2}{|c|}{ ATRYBUTY PRZYWÓDCY XXI WIEKU } \\
\hline \multicolumn{2}{|c|}{ Predyspozycje osobowościowe } \\
\hline \multicolumn{2}{|c|}{$\begin{array}{l}\text { Stosunek do samego siebie: autorefleksja na temat samego siebie; wzmożona świadomość własnego po- } \\
\text { tencjału; nieprzeciętne zaangażowanie w pracę; chęć zdobywania nowej wiedzy; świadomość celów własnegc } \\
\text { wysiłku; poczucie osobistej odpowiedzialności; umiejętność zarządzania własnymi kompetencjami }\end{array}$} \\
\hline \multicolumn{2}{|c|}{$\begin{array}{l}\text { Cechy osobowościowe: pewność siebie; nastawienie na samorealizację; aktywność; pozytywne poczucie } \\
\text { własnej wartości; niezależność; umiejętność podejmowania decyzji; elastyczność w myśleniu i działaniu; } \\
\text { energiczność; łatwość wypowiadania się }\end{array}$} \\
\hline \multicolumn{2}{|c|}{$\begin{array}{l}\text { Atrybuty pozaracjonalne: rozwinięta intuicja psychologiczna; siódmy zmysł; mentalność; cechy psychiczne; } \\
\text { szeroki horyzont myślowy }\end{array}$} \\
\hline \multicolumn{2}{|c|}{ Predyspozycje intelektualne } \\
\hline \multicolumn{2}{|c|}{ Inteligencja emocjonalna: umiejętności tworzenia więzi międzyludzkich; komunikatywność; empatia } \\
\hline \multicolumn{2}{|c|}{$\begin{array}{l}\text { Inteligencja interpers onalna (społeczna, refleksyjna): siła emocjonalna; pasja; umiejętność uczenia się } \\
\text { od innych; umiejętność i chęć dzielenia się władzą; pozytywne nastawienie do otoczenia; otwartość na nowości } \\
\text { naukowe; gotowość na doraźne zmiany }\end{array}$} \\
\hline \multicolumn{2}{|c|}{$\begin{array}{l}\text { Inteligencja logiczna: podejmowanie samodzielnych decyzji; alokacja zdolności umysłowych; przewi- } \\
\text { dywanie przyszłych zdarzeń i ich skutków; umiejętność trafnych wyborów w nieprzewidzianych sytuacjach; } \\
\text { zwięzłe i jasne wyrażanie myśli }\end{array}$} \\
\hline \multicolumn{2}{|c|}{$\begin{array}{l}\text { Umiejętności decyzyjne: ponoszenie odpowiedzialności za przebieg wydarzeń; odwaga i zdecydowanie } \\
\text { w podejmowaniu decyzji; entuzjastyczne kreowanie własnych pomysłów; trafność podczas doboru strategii } \\
\text { decyzyjnych }\end{array}$} \\
\hline \multicolumn{2}{|c|}{ Predyspozycje względem } \\
\hline & \\
\hline & $\begin{array}{l}\text { Stosunek do z } \\
\text { do wpasowania } \\
\text { lecz dążyć do krec } \\
\text { eksponowania za }\end{array}$ \\
\hline $\begin{array}{l}\mathrm{D} z \\
\text { sacl } \\
\text { zyy } \\
\text { się }\end{array}$ & $\begin{array}{l}\text { Działa } \\
\text { kierunku } \\
\text { świadcze } \\
\text { na innov }\end{array}$ \\
\hline & \\
\hline $\begin{array}{l}\text { Stosunek do drugiego człowieka: elastyczność } \\
\text { w działaniu; komunikatywność; uczciwość; takt; spra- } \\
\text { wiedliwość; życzliwość }\end{array}$ & $\begin{array}{l}\text { Stosunek do klienta: poszanowanie odmienności } \\
\text { innych ludzi; umiejętność wzbudzania zaufania; po- } \\
\text { szanowanie prawa }\end{array}$ \\
\hline
\end{tabular}


Z zestawienia w tabeli 1 wynika, że zmiany, jakie obecnie zachodzą w otoczeniu, skłaniają menedżerów do podejmowania nowych wyzwań w różnych dyscyplinach oraz do poszukiwania ponadprzeciętnego sposobu pracy i myślenia (Dźwigoł, 2014). Współcześnie zmiany są jedynym stałym elementem w funkcjonowaniu każdego przedsiębiorstwa, obejmują bowiem każdą płaszczyznę rozwoju organizacyjnego (tj. zmianę technologii, promocji, strategii marketingu, zmianę form komunikacji personalnej, zmianę modeli zarządzania oraz sposobów organizacji), dzięki czemu stwarzają konieczność pojawienia się zupełnie nowego typu menedżera, nastawionego na elastyczność i szybkość w działaniu, posiadającego inwencję twórczą, kreatywność, inteligencję oraz dużą dozę wyobraźni (Kiełtyka, 2016). Niezwykle cenny okazuje się przywódca odważny, zmierzający ku lepszej organizacji, wprowadzający liczne zmiany, które umożliwiają podejmowanie nowych i zarazem zyskownych działań (Drucker, 1992). Współczesny lider jest zobligowany do (Kaczmarek, 2014):

- planowania przyszłości z dużą dokładnością i na wiele lat,

- przewidywania i oceny przyszłych wydarzeń, oczekiwania na nie i ich umiejętnego wykorzystywania,

- przygotowania różnych wariantów rozwiązań na różne ewentualności,

- stałego podejmowania mniej lub bardziej odważnych decyzji, które są obarczone dużym ryzykiem,

- wychodzenia naprzeciw różnym wydarzeniom, wykorzystując odpowiednie informacje.

Przedsiębiorca XXI wieku powinien posiadać umiejętność dialektycznego działania i myślenia, a więc zdolność do umiejętnego rozpoznawania sprzeczności wewnętrznych oraz doboru adekwatnych rozwiązań, które umożliwią wdrożenie koniecznych zmian naprawczych wewnątrz organizacji (Zankovsky \& von der Heiden, 2019). Prawdopodobnie przyszłość wskaże nowy wizerunek idealnego menedżera, a globalna konkurencja znacząco zaostrzy wymagania odnoszące się do „doskonałości” przywódców. Jednak aby przedsiębiorstwo przetrwało, jego przywódca wciąż będzie zobligowany do wprowadzania innowacji, nowych procesów pracy, nowych form promocji i marketingu, niepowtarzalnych produktów i usług oraz do stosowania „totalnej jakości pracy”, pozbawionej nadmiernych zapasów, defektów, opóźnień, przestojów czy rozbudowanej dokumentacji (Kaczmarek, 2014). Niewątpliwie menedżer przyszłości musi dostrzegać zmiany zachodzące w otoczeniu organizacji i dostosowywać strategię działania do wyzwań obejmujących sferę społeczną, technologiczną i globalną.

\section{Wyzwania wspólczesnych organizacji}

Zarządzanie organizacją XXI wieku obliguje do zrozumienia i akceptacji złożoności, wieloaspektowości i zmienności, za powszechne zjawiska uznaje się bowiem niestabilność i płynność struktury wewnętrznej organizacji. Nowoczesne zarządza- 
nie opiera się na systemie wielokierunkowych powiązań procesów, podsystemów i projektów przy jednoczesnym ukierunkowaniu na pracę zespołową w wielodyscyplinarnym składzie osobowym (Dźwigoł, 2014). W tabeli 2 uwzględniono współczesne zmiany zachodzące $w$ organizacji i jej otoczeniu, a także rezultaty tych zmian z perspektywy funkcjonowania przedsiębiorstwa XXI wieku.

Tabela 2. Zmiany zachodzące we współczesnej organizacji i jej otoczeniu oraz ich skutki

\begin{tabular}{|c|c|}
\hline \multicolumn{2}{|c|}{ Zmiany } \\
\hline w organizacji & w otoczeniu organizacji \\
\hline $\begin{array}{l}\text { Zmiana samych organizacji (szybkie, elastyczne, } \\
\text { wirtualne) }\end{array}$ & $\begin{array}{l}\text { Zmiana środowiska, w którym funkcjonuje } \\
\text { organizacja }\end{array}$ \\
\hline Zmienność granic organizacji & Powstanie nowych segmentów rynku \\
\hline Nowe kanały dystrybucji & Pojawianie się nowych potrzeb klientów \\
\hline $\begin{array}{l}\text { Zmiana specyfiki pracy (oparta na wiedzy, bardziej } \\
\text { skomplikowana) }\end{array}$ & Upowszechnienie się wiedzy i informacji \\
\hline Wielokulturowy zespół & Globalizacja \\
\hline Pluralizm opinii, zindywidualizowana świadomość & Internacjonalizacja \\
\hline $\begin{array}{l}\text { Nowe spojrzenie na pojęcie przywództwa } \\
\text { (transformacyjne, charyzmatyczne, autentyczne, } \\
\text { symboliczne) }\end{array}$ & Tworzenie społeczeństwa informatycznego \\
\hline $\begin{array}{l}\text { Zmiana roli lidera w organizacji (zwiększona } \\
\text { odpowiedzialność i ryzyko podejmowane przez } \\
\text { przywódcę) }\end{array}$ & Liberalizm kulturowy \\
\hline $\begin{array}{l}\text { Aktywizacja poszukiwań innowacji przez } \\
\text { koncentrację na triadzie: informacja - kapitał ludzki } \\
\text { - kreatywność }\end{array}$ & $\begin{array}{l}\text { Nowe wartości, aspiracje i potrzeby młodego } \\
\text { pokolenia }\end{array}$ \\
\hline $\begin{array}{l}\text { Generowanie dużej ilości informacji niepewnych } \\
\text { i podatnych na dezaktualizację }\end{array}$ & Wzrost znaczenia kapitału intelektualnego \\
\hline Wzrost niepewności sytuacji decyzyjnych & Wirtualizacja \\
\hline Nowa relacja kierownictwo - pracownicy & \multirow[t]{2}{*}{ Upowszechnienie sieci i powiązań sieciowych } \\
\hline $\begin{array}{l}\text { Nowy sposób kontaktowania się z klientami } \\
\text { i dostawcami }\end{array}$ & \\
\hline \multicolumn{2}{|c|}{ Skutki zmian } \\
\hline $\begin{array}{l}\text { Zarządzanie oparte na wiedzy } \\
\text { Zmienność zasobów } \\
\text { Innowacyjność } \\
\text { Etyka, ekologia i ochrona środowiska } \\
\text { Kreowanie nowych wartości } \\
\text { Pozorne zyski współdziałania przedsiębiorstw } \\
\text { Poszukiwanie doskonałości } \\
\text { Społeczna odpowiedzialność przedsiębiorstw } \\
\text { Elastyczność w działaniu } \\
\text { Zarządzanie przez wizję }\end{array}$ & \\
\hline
\end{tabular}

Źródło: opracowanie własne na podstawie (Kaczmarek, 2014; Penc-Pietrzak, 2015; Zankovsky \& von der Heiden, 2019).

Z tabeli 2 wynika, że przedsiębiorstwa znajdujące się w nowej, globalnej rzeczywistości, aby utrzymać swoją pozycję na rynku, muszą nieustannie przewidywać, a także dokonywać trafnej oceny swojej sytuacji oraz podejmować decyzje dotyczące formy, sposobu, zakresu, tempa realizacji, kompleksowości i głębokości wprowa- 
dzanych zmian strukturalnych. Wskazane działania są wyznacznikami przetrwania, równowagi, formułowania dynamicznych zamierzeń, dalszego rozwoju oraz uzyskiwania trwałej przewagi konkurencyjnej (Borowiecki, 2011).

Niewątpliwie coraz bardziej turbulentne otoczenie wymusza na przywódcach przebudowę systemową, nabywanie nowych działań, procedur i cech oraz wdrażanie nowoczesnych metod zarządzania. Sukces współczesnych organizacji zależy od doceniania różnorodności kulturowej, myślenia globalnego czy działań opartych na systemie wartości, których fundamentem są zasady moralne i etyka biznesu (Kubik, 2001). Osiągnięcie wysokiej pozycji konkurencyjnej oraz ograniczenie ryzyka i niepewności jest możliwe dzięki wprowadzaniu nowatorskich rozwiązań i maksymalizacji sumy korzyści wynikających z operacji przeprowadzanych na skalę światową (Penc, 2000). W tabeli 3 uwzględniono wyzwania społeczne, technologiczne i globalne, jakim musi sprostać przedsiębiorstwo XXI wieku.

Tabela 3. Wyzwania współczesnych organizacji

\begin{tabular}{|c|c|}
\hline \multicolumn{2}{|r|}{ Wyzwania współczesnych organizacji } \\
\hline Społeczne & $\begin{array}{l}\text { - działanie w sposób społecznie odpowiedzialny } \\
\text { - traktowanie zysków jako jeden z głównych celów organizacji, a nie jako rację bytu } \\
\text { - podejmowanie długookresowych decyzji inwestycyjnych i strategicznych przy } \\
\text { uwzględnieniu ekonomicznych i społecznych konsekwencji } \\
\text { - jednoczenie pracowników wokół wspólnych celów i wartości } \\
\text { - stałe, obopólne i długookresowe korzystne relacje przedsiębiorstwa z klientami, } \\
\text { społeczeństwem, dostawcami, partnerami, pracownikami i innymi podmiotami } \\
\text { - dążenie do równowagi w rozwoju pracowników, firmy i środowiska } \\
\text { - ochrona środowiska przed działaniami szkodliwymi } \\
\text { - zapewnienie korzystnych form zatrudnienia i godziwych zarobków pracownikom } \\
\text { - zapewnienie partnerskich warunków współpracy z otoczeniem zewnętrznym } \\
\text { - dbanie o pozytywny wizerunek organizacji i kreatywne uczestnictwo w jej rozwoju } \\
\text { - system wartości zgodny z zasadami moralnymi i etyką biznesu }\end{array}$ \\
\hline Technologiczne & $\begin{array}{l}\text { - czwarta rewolucja przemysłowa (Industry 4.0) } \\
\text { - szybkość i jakość przekazywanej informacji } \\
\text { - rozwój technologii informacyjno-komunikacyjnych (tzw. ICT) } \\
\text { - dynamiczny i nieprzewidywalny rozwój techniki i technologii, zmuszający do ciągłego } \\
\text { doskonalenia i uczenia się } \\
\text { - opieranie procesów decyzyjnych na przetwarzaniu danych w czasie rzeczywistym } \\
\text { i bazowanie na wirtualnych symulacjach } \\
\text { - komunikacja na płaszczyźnie maszyna - maszyna oraz maszyna - człowiek } \\
\text { - nowe technologie wytwórcze } \\
\text { - rosnąca potrzeba budowy i współpracy w ramach cyberfizycznych systemów } \\
\text { - tworzenie w pełni zintegrowanego systemu producentów, klientów i dostawców } \\
\text { - postrzeganie technologii jako narzędzia do tworzenia nowych struktur organizacyjnych, } \\
\text { zwiększania produktywności, odpowiadania na potrzeby klientów oraz zarządzania wiedzą }\end{array}$ \\
\hline Globalne & $\begin{array}{l}\text { - umiędzynarodowienie zarządzania } \\
\text { - nabycie nowych umiejętności (dostosowanie kulturowe) } \\
\text { - tworzenie przedsiębiorstwa przyszłości (sieciowego, wirtualnego) } \\
\text { - zmiany potrzeb społecznych, technik i technologii (decentralizacja) } \\
\text { - nieustanna motywacja do stałego uczenia się } \\
\text { - zatrudnianie przedsiębiorczej kadry } \\
\text { - orientacja na wyniki } \\
\text { - wiedza interdyscyplinarna }\end{array}$ \\
\hline
\end{tabular}




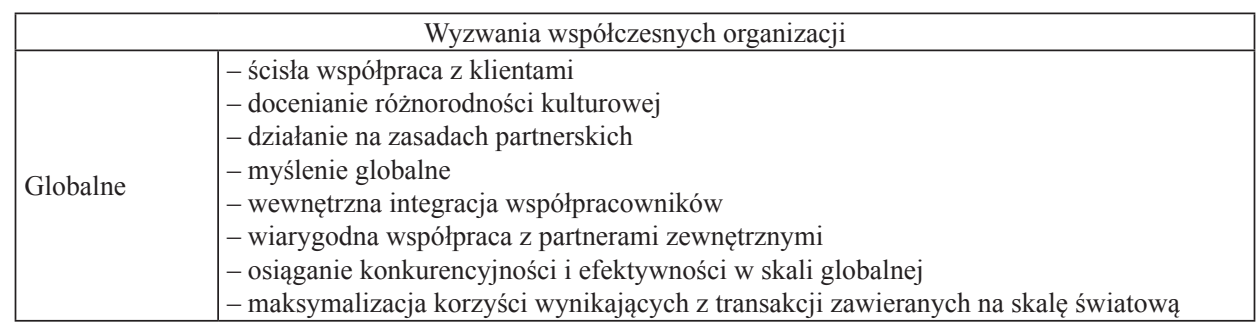

Źródło: opracowanie własne na podstawie (Kaczmarek, 2014; Kubik, 2012; Miśkiewicz, 2018; Skala, 2018; Tomaszewski, 2018).

W dynamicznie postępującej erze informacji następuje zatem radykalna zmiana otoczenia przedsiębiorstwa, które zyskuje miano burzliwego. Za kluczowy czynnik sukcesu uznaje się nieograniczone zasoby niematerialne, a znaczenia nabierają relacje organizacji z jej otoczeniem poprzez upowszechnianie zależności sieci w postaci ujemnych i dodatnich sprzężeń zwrotnych. Granice funkcjonowania organizacji stają się rozmyte, a planowanie traci wiodącą rolę, przyjmując charakter panowania nad powstałym chaosem. Obecnie czas uznawany jest za najistotniejszy zasób strategiczny, a kluczowym czynnikiem sukcesu jest szybkość w wymiarze indywidualnym i zbiorowym (Skalik, 2018). W efekcie przedsiębiorstwa XXI wieku muszą ewoluować w kierunku organizacji opartych na wiedzy, a więc organizacji inteligentnych, które dążą do zastosowania w praktyce zdobytej wiedzy oraz tworzenia nowej. Dzięki temu mają one możliwość rozpoznania pojawiających się zmian, dynamicznej adaptacji do nich, wprowadzania innowacyjnych rozwiązań i wdrażania skutecznego zarządzania strategicznego (Kubik, 2012). Miejscem, które umiejętnie łączy wyzwania turbulentnego otoczenia, zmiany w nim zachodzące oraz potrzeby potencjalnych klientów, jest Dolina Krzemowa. Uznawana za kolebkę innowacyjnych rozwiązań, charakteryzuje się szczególnym doświadczeniem w zakresie idealnego zarządzania wyróżniającymi kompetencjami, nastawionego na stały rozwój i doskonalenie w celu osiągnięcia sukcesu rynkowego.

\section{Kluczowe czynniki sukcesu Doliny Krzemowej źródłem inspiracji dla wspólczesnych przedsiębiorców}

Dolina Krzemowa (Latusek-Jurczak, 2013) w USA to region stanowiący awangardę styku biznesu i technologii, a także obszar uznany za niekwestionowany i nadzwyczajny ośrodek lidera innowacyjności. Wzbudza zainteresowanie nie tylko badaczy, lecz także praktyków biznesu z całego świata, którzy próbują naśladować i zrozumieć jej osiągnięcia. Wyjątkowy charakter zyskuje dzięki długotrwałej przewadze konkurencyjnej oraz skali innowacyjności. Jej rozkwit rozpoczął się w latach 70. XX wieku, kiedy to wynaleziono obwody scalone i w konsekwencji zdecydowano się na masową produkcję chipów, co doprowadziło do spopularyzowania 
komputerów osobistych (PC). Wytwarzane tam produkty i usługi w dynamicznym tempie rozprzestrzeniają się na cały świat, a firmy tam utworzone dominują na rynkach światowych.

Niewątpliwie do czynników, które wspierają ten region, należy zaliczyć wydarzenia historyczne, klimat, jaki panuje w stanie Kalifornia, obecność światowych wizjonerów oraz tworzenie przełomowych innowacji (Knop, 2016). Dolina Krzemowa to miejsce, które wyróżnia energia, ogromna kultura współpracy, niepowtarzalna mentalność (docenianie sukcesu i porażki, która stanowi okazję do uczenia się), wyjątkowe wsparcie ze strony rządu dla działalności $\mathrm{B}+\mathrm{R}$, a także rozbudowany ekosystem instytucji finansujących (Latusek-Jurczak, 2013). Dolina Krzemowa to również zbiór światowej sławy innowatorów, których cechuje globalne podejście do całego biznesu i rozwoju produktu (Knop, 2016). Jest regionem skutecznego „rozlewania się wiedzy” pomiędzy poszczególnymi przedsiębiorstwami. Ponadto cechuje ją dostęp do wysoko wykwalifikowanej siły roboczej o wyjątkowej mobilności oraz gęsta sieć kontaktów, które zapewniają trwałą przewagę konkurencyjną dzięki wymianie wiedzy i cennych informacji (Mika, 2017). W tabeli 4 zaprezentowano kluczowe czynniki sukcesu Doliny Krzemowej z uwzględnieniem specyfiki zakładanych tam firm i zatrudnionej w nich siły roboczej, panującej kultury biznesowej, wpływu instytucji zewnętrznych i wsparcia rządowego oraz uwarunkowań rynkowych i lokalizacyjnych.

Tabela 4. Kluczowe czynniki sukcesu Doliny Krzemowej

\begin{tabular}{|c|c|}
\hline \multicolumn{2}{|r|}{ Kluczowe czynniki sukcesu Doliny Krzemowej } \\
\hline Specyfika firm & $\begin{array}{l}\text { - uwzględnianie ryzyka i porażki w ramach działalności biznesowej } \\
\text { - ideowość, kreatywność, rzetelność i odporność przedsiębiorców i pracowników } \\
\text { - zdolność do przyciągania talentów } \\
\text { - tolerancja dla ekscentrycznych wynalazków i niekonwencjonalnych pomysłów }\end{array}$ \\
\hline Specyfika siły roboczej & $\begin{array}{l}\text { - wielokulturowe środowisko } \\
\text { - intensywność wiedzy } \\
\text { - doświadczenie, talent i ambicja } \\
\text { - zdrowy styl życia i wysoka kultura pracy } \\
\text { - wysoko kwalifikowana siła robocza } \\
\text { - dostępność fachowej kadry zarządzającej } \\
\text { - wytrwałość, dojrzałość, pasja, pewność siebie } \\
\text { - wyróżniająca aktywność w różnych dziedzinach }\end{array}$ \\
\hline Kultura biznesowa & $\begin{array}{l}\text { - kultura dzielenia się wiedzą, kontaktami i doświadczeniem } \\
\text { - wymiana pomysłów } \\
\text { - tworzenie tzw. otwartych innowacji } \\
\text { - otwartość na różne kultury } \\
\text { - kultura współpracy } \\
\text { - presja działania } \\
\text { - tworzenie nowych firm i rozwijanie już istniejących }\end{array}$ \\
\hline $\begin{array}{l}\text { Wpływ instytucji } \\
\text { zewnętrznych }\end{array}$ & $\begin{array}{l}\text { - obecność wiodących ośrodków naukowo-badawczych i szkół wyższych } \\
\text { - silna reprezentacja przedstawicieli funduszy venture capital i aniołów biznesu } \\
\text { - obecność dużych firm technologicznych i instytutów badawczych } \\
\text { - wsparcie ze strony wyspecjalizowanych organizacji akceleracyjnych i inkuba- } \\
\text { torów przedsiębiorczości }\end{array}$ \\
\hline
\end{tabular}


Pobrane z czasopisma Annales H - Oeconomia http://oeconomia.annales.umcs.pl

Data: 26/04/2023 13:34:30

PATRYCJA MARZEC

\begin{tabular}{|l|l|}
\hline \multicolumn{2}{|c|}{ Kluczowe czynniki sukcesu Doliny Krzemowej } \\
\hline Wsparcie rządowe & $\begin{array}{l}\text { - odpowiednie regulacje prawne dotyczące patentów } \\
\text { - przychylne prawo federalne }\end{array}$ \\
\hline $\begin{array}{l}\text { Uwarunkowania } \\
\text { rynkowe }\end{array}$ & $\begin{array}{l}\text { - duży popyanie silnego rynku produkty i usługi } \\
\text { - liczne powiązania z innymi rynkami } \\
\text { - gęste sieci przemysłowe } \\
\text { - wysokiej jakości rynki pracy }\end{array}$ \\
\hline $\begin{array}{l}\text { Uwarunkowania } \\
\text { lokalizacyjne }\end{array}$ & - optymalna populacja i powierzchnia \\
\hline
\end{tabular}

Źródło: opracowanie własne na podstawie (Latusek-Jurczak, 2013; Lipińska, 2018; PARP, 2015; Sagan \& Wiśniewska, 2018; Wonglimpiyarat, 2006).

Z tabeli 4 wynika, że sukces Doliny Krzemowej jest uwarunkowany w szczególności panującym tam niepowtarzalnym klimatem, prężnie rozwijającą się komunikacją, obfitością szkół wyższych i licznych instytucji wspierających, doskonałą współpracą na płaszczyźnie nauki i biznesu, różnorodnością kulturową, „wyrafinowaną" i wyjątkową wiedzą, a także otwartością na nowe wyzwania (Knop, 2016). Z kolei właściwościami, które sprzyjają tworzeniu bogactwa tego regionu, są wyróżniająca energia ludzi odważnie myślących, gotówka poszukująca możliwości pomnożenia oraz nieograniczona wyobraźnia innowatorów (Hamel, 1999).

Dolina Krzemowa jest siedliskiem przedsiębiorczości i innowacji, dlatego zyskała miano najbardziej dynamicznego regionu gospodarczego na świecie. Z kolei wyróżniająca kultura, liczne sieci relacji oraz wiodąca pozycja w branży umożliwiają prężnie działającym tam firmom pozyskiwanie lojalnych klientów, a także przyciąganie ambitnych i utalentowanych pracowników (Trunina, Liu, \& Chen, 2018). Przedsiębiorcy z Doliny Krzemowej koncentrują się na wykorzystywaniu zaawansowanych technologii, powstających $\mathrm{w}$ oparciu o innowacje mające bardziej radykalny niż przyrostowy charakter (Audretsch, 2019). Dodatkowo dążą do mobilności zasobów ludzkich, finansowych i informacyjnych tak, aby zapewnić pełen wachlarz możliwości wielu przedsiębiorstwom jednocześnie oraz rozprzestrzeniają rozwiązania technologiczne, co ułatwia współpracę i komunikację pomiędzy podmiotami. Ponadto „tolerują niepowodzenia”, które przyczyniają się do tworzenia lepszych, niepowtarzalnych rozwiązań. Priorytetowym celem przedsiębiorstw z Doliny Krzemowej jest wejście na rynek globalny oraz umiejętność dynamicznego dostosowania się do radykalnych zmian (Engel, 2015).

Wielu próbowało naśladować działalność firm Doliny Krzemowej. Niestety, próba odtworzenia przedsiębiorstw wysokich technologii, zdolnych do wprowadzania seryjnych innowacji w dość długim okresie, w innych miejscach świata najczęściej kończyła się porażką (Latusek-Jurczak, 2013). Fundamentalnym problemem regionów próbujących naśladować te rozwiązania w krajach rozwiniętych jest brak kosztownych nakładów finansowych na kapitał ludzki i nową wiedzę, co w efekcie prowadzi do problemów związanych z integracją gospodarczą i społeczną (Audretsch, 2019). Należy podkreślić, że Dolina Krzemowa jest specyficznym regio- 
nem, posiadającym odpowiednią infrastrukturę, wspomaganą przez liczne platformy komunikacji oraz rozbudowane otoczenie zachęcające do spotkań towarzyskich i biznesowych. To miejsce, w którym występuje sprawna sieć komunikacyjna oraz dobra jakość życia i pozytywne relacje pomiędzy nauką a biznesem. Obecność renomowanych szkół wyższych przyczynia się do edukacji inteligentnych i zdolnych pracowników, a różnorodne środowisko i doświadczeni finansiści umożliwiają podejmowanie przedsięwzięć na skalę globalną. Sukces zapewniają też przedsiębiorczy mieszkańcy, nastawieni na współpracę i wyróżniający się kulturą innowacyjności, która koncentruje się na zaspokojeniu potrzeb finalnego odbiorcy (Knop, 2016).

\section{Zakończenie}

Na podstawie powyższych rozważań należy stwierdzić, że współczesny menedżer - posługując się odpowiednią kombinacją posiadanych zasobów - powinien w umiejętny sposób godzić ze sobą często rozbieżne wymagania. Z jednej strony powinien myśleć lokalnie, $z$ drugiej zaś globalnie. Poza tym powinien systematycznie podnosić jakość oferowanych produktów i dbać o wizerunek samej organizacji, a także kierować się ideą społecznej odpowiedzialności, konkurować i współpracować, kierować się zyskiem i zarazem dbać o potrzeby swoich pracowników. Dodatkowo - jako przywódca na miarę XXI wieku - zobligowany jest do sukcesywnego testowania i tworzenia innowacyjnych metod $\mathrm{i}$ koncepcji zarządzania, stymulowania kreatywności, szerzenia idei organizacji uczącej się oraz współpracy opartej na dzieleniu się wiedzą, informacjami i doświadczeniem w ramach sieci tworzonych w wielokulturowym środowisku.

Jednocześnie współczesny przedsiębiorca musi sprostać coraz bardziej złożonym i rygorystycznym wyzwaniom społecznym, technologicznym czy globalnym. Jest zobligowany do zapewnienia partnerskich warunków współpracy z otoczeniem zewnętrznym. Powinien jednoczyć pracowników wokół wspólnych celów i wartości oraz dążyć do ustawicznego doskonalenia i uczenia się ze względu na dynamiczny i nieprzewidywalny rozwój techniki i technologii. Niezwykle istotne w jego działalności jest myślenie globalne, uwzględniające szerzące się umiędzynarodowienie zarządzania, dostosowywanie się do zachowań wielokulturowych oraz tworzenie przedsiębiorstwa przyszłości opartego na rozwiązaniach sieciowych i wirtualizacji.

Kolebką przedsiębiorstw umiejętnie pokonujących te wyzwania jest Dolina Krzemowa - region, który swój sukces zawdzięcza niepowtarzalnej atmosferze szerzącej się przedsiębiorczości, innowacyjności, odwagi, energii, nieograniczonej wiedzy i otwartości na nowe wyzwania. Dodatkowo obecność wiodących ośrodków naukowo-badawczych i wsparcie rządowe przyczyniają się do doskonałej współpracy na płaszczyźnie nauki i biznesu. Z kolei otwartość na różne kultury oraz tolerancja dla ekscentrycznych wynalazków i niekonwencjonalnych pomysłów umożliwiają tworzenie niepowtarzalnych wartości dla klienta. Wielu próbowało odwzorować 
sukces Doliny Krzemowej - niestety bezskutecznie. Tego typu osiągnięcia nie zależą bowiem jedynie od przedsiębiorców, lecz także od otoczenia, instytucji wspierających, infrastruktury i przedsiębiorczych mieszkańców, a co za tym idzie panującej kultury. Dlatego współcześni przedsiębiorcy powinni dynamicznie dostosowywać się do rosnących wymagań klientów oraz na pierwszym miejscu stawiać potencjał ludzki, który dzięki wyróżniającym kompetencjom, a w szczególności posiadanej wiedzy, będzie najcenniejszym majątkiem przedsiębiorstwa przyszłości oraz kluczowym zasobem niematerialnym rozwijającej się gospodarki.

\section{Bibliografia}

Audretsch, D.B. (2019). Have we oversold the Silicon Valley model of entrepreneurship? Small Business Economics. doi:10.1007/s11187-019-00272-4

Bass, B.M., \& Bass, R. (2008). The Bass Handbook of Leadership. New York: Free Press.

Borowiecki, R. (2011). Przedsiębiorstwo w obliczu wyzwań współczesnej gospodarki. Nierówności Spoteczne a Wzrost Gospodarczy, 20, 5-15.

Drucker, P.F. (1992). Innowacja i przedsiębiorczość. Praktyka i zasady. Warszawa: PWE.

Dźwigoł, H. (2014). Menedżerowie przyszłości a zarządzanie strategiczne. Zeszyty Naukowe Politechniki Śląskiej. Organizacja i Zarządzanie, 70, 93-104.

Engel, J.S. (2015). Global Clusters of Innovation: Lessons from Silicon Valley. California Management Review. 57(2). doi:10.1525/cmr.2015.57.2.36

Geryk, M. (2016). Rola przywódcy a skuteczne zarządzanie organizacją w zmiennym otoczeniu. W: M. Geryk, A. Pławska (red.), Współczesna problematyka wybranych zagadnień prawnych i ekonomicznych. Gdańsk: WSZ.

Hamel, G. (1999). Bringing Silicon Valley Inside. Harvard Business Review, (September).

Jago, A.G. (1982). Leadership: Perspectives in theory and research. Management Science, 28(3), 221-339. doi:10.1287/mnsc.28.3.315

Kaczmarek, B. (2014). Wyzwania dla współczesnych przedsiębiorstw i menedżerów - zarys problematyki. Research Papers of the Wroclaw University of Economics / Prace Naukowe Uniwersytetu Ekonomicznego we Wroctawiu, 340, 701-711. doi:10.15611/pn.2014.340.62

Kiełtyka, L. (2016). Rola menedżera we współczesnych organizacjach. Przegląd Organizacji, 8, 4-10. doi:10.33141/po.2016.08.01

Klimka-Kołysko, M. (2018). Kariera na współczesnym rynku pracy. Szanse i wyzwania dla pracowników przygotowujących się do wejścia na rynek pracy. Przedsiębiorczość i Zarządzanie, 19(8.3), 257-271.

Knop, L. (2016). Trwałość klastra w kontekście doświadczeń Doliny Krzemowej. Zeszyty Naukowe Politechniki Śląskiej. Organizacja i Zarzązanie, 90, 45-62.

Kotter, J.P. (2001). What leaders really do. Harvard Business Review, 79(11). Pobrane z: http://fs.ncaa.org/ Docs/DIII/What\%20Leaders\%20Really\%20Do.pdf

Kubik, K. (2001). Uwarunkowania sukcesu zawodowego kadry kierowniczej. Warszawa: SGH.

Kubik, K. (2012). Współczesne przedsiębiorstwa wobec wyzwań globalnej konkurencji. Zeszyty Naukowe Uniwersytetu Przyrodniczo-Humanistycznego w Siedlcach. Seria: Administracja i Zarzadzanie, 19(92), 33-49.

Latusek-Jurczak, D. (2013). Dolina Krzemowa i inne regiony rozwijające przemysły wysokich technologii. W: R. Bobrowiecki, T. Rojek (red.), Kooperencja przedsiębiorstw w gospodarce rynkowej. Konkurencja-kooperacja-rozwój. Kraków: Uniwersytet Ekonomiczny w Krakowie. 
Lipińska, A. (2018). Koncepcje i kluczowe czynniki rozwoju ekosystemów startupów. Studia Ekonomiczne, $351,46-57$.

Mika, B. (2017). Pingwin czy orzeł? Społeczny charakter wiedzy na przykładzie kalifornijskiej Doliny Krzemowej. Studia Krytyczne, 4, 131-150.

Miśkiewicz, R. (2018). Przedsiębiorstwa we współczesnej gospodarce globalnej. Zeszyty Naukowe Politechniki Ślaskiej. Organizacja i Zarządzanie, 118, 407-418. doi:10.29119/1641-3466.2018.118.30

PARP. (2015). Zaistnieć w Dolinie Krzemowej - dobre praktyki projektu Polski Most Krzemowy. Pobrane z: www.parp.gov.pl/storage/publications/pdf/dobre\%20praktyki\%20projektu\%20pmk.pdf

Penc, J. (2000). Kreatywne kierowanie. Organizacja i kierownik jutra, rozwiązywanie problemów kadrowych. Warszawa: Agencja Wydawnicza Placet.

Penc-Pietrzak, I. (2015). Charakterystyka zdolności dynamicznych przedsiębiorstwa w warunkach hiperkonkurencji. Studia Ekonomiczne. Zeszyty Naukowe Uniwersytetu Ekonomicznego w Katowicach, $229,143-156$.

Sagan, M., \& Wiśniewska, E. (2018). Tworzenie ekosystemu start-upowego w Lublinie jako narzędzie przełamywania peryferyzacji regionu. Zeszyty Naukowe WSEI. Seria: Ekonomia, 15(1), 7-26.

Skala, A. (2018). Wpływ nowych technologii na zarządzanie - startupy jako biznesowe, organizacyjne i technologiczne wyzwania współczesnego zarządzania. Przegląd Organizacji, 6, 66-72.

Skalik, J. (2018). Sukces w zarządzaniu zmianami organizacyjnymi - współczesne uwarunkowania i możliwości jego osiągnięcia. Zarządzanie i Finanse, 16(1.1), 203-216.

Tomaszewski, A. (2018). Współczesne organizacje w kontekście potrzeb społecznych. Zeszyty Naukowe Politechniki Śląskiej. Organizacja i Zarządzanie, 128, 387-407. doi:10.29119/1641-3466.2018.128.30

Trunina, A., Liu, X., \& Chen, J. (2018). Small and medium technology enterprises in Zhongguancun and Silicon Valley: Regional innovation system approach. Journal of Science and Technology Policy Management, 10(1). doi:10.1108/JSTPM-01-2018-0006

Wonglimpiyarat, J. (2006). The dynamic economic engine at Silicon Valley and US government programs in financing innovations. Technovation, 26(9), 1081-1089. doi:10.1016/j.technovation.2005.09.005

Zankovsky, A., \& von der Heiden, C. (2019). Przywództwo z Synercube. Dynamiczna kultura przywództwa $w$ dążeniu do doskonałości. Berlin-Heidelberg: Springer. doi:10.1007/978-3-662-58235-0

Zgoda, Z., Nowakowska, A., \& Nowakowska, L. (2017). Etyczny wymiar przywództwa w organizacji. Studies \& Proceedings of Polish Association for Knowledge Management, 85, 71-79. 